\title{
Short Hairpin RNA
}

National Cancer Institute

\section{Source}

National Cancer Institute. Short Hairpin RNA. NCI Thesaurus. Code C123893.

An artificial RNA molecule with a tight hairpin turn that can be used to silence target gene expression via RNA interference (RNAi). 